\title{
Acute Viral Hepatitis in Pediatric Age Groups
}

\author{
Sudhamshu KC, ${ }^{1}$ Dilip Sharma, ${ }^{1}$ Nandu Poudyal, ${ }^{2}$ Bhupendra Kumar Basnet ${ }^{2}$ \\ 'Liver Unit, Department of Medicine, Bir Hospital, National Academy of Medical Sciences, Kathmandu, Nepal, ${ }^{2}$ Department \\ of Medicine, Bir Hospital, National Academy of Medical Sciences, Kathmandu, Nepal.
}

\section{ABSTRACT}

Introduction: Our clinical experience showed that there has been no decrease in pediatric cases of acute viral hepatitis in Kathmandu. The objective of the study was to analyze the etiology, clinical features, laboratory parameters, sonological findings and other to determine the probable prognostic factors of Acute Viral Hepatitis in pediatric population.

Methods: Consecutive patients of suspected Acute Viral Hepatitis, below the age of 15 years, attending the liver clinic between January 2006 and December 2010 were studied. After clinical examination they were subjected to blood tests and ultrasound examination of abdomen. The patients were divided in 3 age groups; 0-5, 5-10 and 5-15 years. Clinical features, laboratory parameters, ultrasound findings were compared in three age groups.

Results: Etiology of Acute Viral Hepatitis was Hepatitis A virus 266 (85\%), Hepatitis E virus in 24 (8\%), Hepatitis B virus in $15(5 \%)$. In 7(2\%) patients etiology was unknown. Three patients went to acute liver failure but improved with conservative treatment. There was no statistical difference in most of the parameters studied in different age groups. Ascites was more common in 5-10 years age group. Patients with secondary bacterial infection, ultrasound evidence of prominent biliary tree and ascites were associated with increased duration of illness. Patients with history of herbal medications had prolonged cholestasis.

Conclusions: Hepatitis A is most common cause of Acute Viral Hepatitis in pediatric population. Improper use of herbal medications, secondary bacterial infection and faulty dietary intake was associated with prolonged illness. Patients with prominent biliary radicals should be treated with antibiotics even with normal blood counts for earlier recovery.

Keywords: acute viral hepatitis; hepatitis A; hepatitis E; herbal medications.

\section{INTRODUCTION}

Owing to poor hygiene and poor sanitation, acute viral hepatitis $(A V H)$ is still endemic in developing country like Nepal. In India, HAV has been identified as the common etiological agent forsporadic $\mathrm{AVH}$, especially in the pediatric age group. ${ }^{1}$ In Nepal all forms of viral hepatitis are seen throughout the year. Hepatitis E virus (HEV) infection is common among adult population, while hepatitis A virus (HAV) infection is common in younger age group. However, no age is immune to both viruses. It is found that $\mathrm{AVH}$ is an important cause of morbidity and mortality in Nepali children. There are several publications on HEV infection in Nepal. However,

Correspondence: Dr. Sudhamshu KC, Liver Unit, Bir Hospital National Academy of Medical Sciences, Kathmandu Nepal. Email: sudhamshu.liver@gmail.com, Phone: +977-9851081599. 
publications on HAV infection, which is more common in pediatric age group, are virtually absent from our country. Our previous clinical experience shows that there has been no decrease in pediatric cases of acute viral hepatitis in Kathmandu. So, this study was aimed to analyze the etiology of $\mathrm{AVH}$ in pediatric population, its clinical features, laboratory parameters, sonological findings and other possible factors to determine the probable prognostic factors of $\mathrm{AVH}$ in this age group.

\section{METHODS}

A cross-sectional study was conducted in liver clinic of Liver unit of Bir hospital and Norvic International hospital of Kathmandu, Nepal from January 2006 and December 2010. Convenience sampling as used as consecutive patients of suspected AVH were enrolled in this study. The consent for the study was taken from parents of the children. Patients presenting with two or more symptoms of loss of appetite, jaundice, nausea, vomiting, pain abdomen and itching were enrolled for evaluation. After history and clinical examination they were subjected to blood tests (complete blood count, liver function tests, prothrombin time, and viral serology for hepatitis A, B and E and ultrasound examination of the abdomen). Those patients having positive viral serology and/or alanine transferase more than 10 times the upper limit were included in the study. History was also focused on dietary habit after development of symptoms and intake of herbal medications. The studied patients were divided in three age groups; $0-5$, 6-10 and 11-15 years. Clinical features, laboratory parameters, ultrasound findings were compared in three age groups. Those patients with previous history of liver diseases were excluded from the study.

Those patients who were very sick were admitted for observation and further management. The indications for admission was poor general condition, not being able to eat properly due to protracted vomiting, high fever, transaminase level more than $3000 \mathrm{IU} / \mathrm{mL}$, prolong prothrombin time (more than six seconds from control) and altered sensorium. If ALT level was $>3000 \mathrm{IU} / \mathrm{mL}$ SNMC (stronger neo-minophagen compound) was given in a dose of $20 \mathrm{ml} /$ day. Antibiotics were used whenever required. Ofloxacin was given to randomly selected patients who presented with prominent intrahepatic biliary duct (IHBD) and ascites. In other cases they were managed conservatively with symptomatic treatment and dietary advice. Statistical analysis and data record were done using Microsoft Excel 2010.

\section{RESULTS}

A total of 368 patients under the age of 15 years attended liver clinic with complaints related to acute viral hepatitis, particularly jaundice and loss of appetite.
There was slight male preponderance. As the age increased, there were more cases. Most of the cases were in the age group of 11-15 years (Table 1). Out of 368 patients 312 were diagnosed as acute viral hepatitis. Gilbert's syndrome was the most common diagnosis among the excluded patients. Second to it was Salmonella hepatitis. The presenting complaints of the studied subjects were variable and are given in Table 2. The most common presenting complaints were jaundice, loss of appetite, vomiting and pain abdomen. There was overlap of many symptoms. Unlike the adult age group many patients presented with history of fever ranging from $100-104^{\circ} \mathrm{F}$. There were many cases of AVH initially investigated and treated as enteric fever and referred to us after blood test showed liver dysfunction or they developed jaundice in due course of illness. Itching was more common with increase in age. Those patients who had previously taken herbal medications had more itching compared to those who had not taken anything prior to consultation. The average time for normalization of bilirubin and enzymes took longer in patients who were exposed to herbal medication. Four readmissions were all due to herbal medicine intake and diet restrictions causing intense pruritus and increase in jaundice. Laboratory parameters are given in Table 3. Regarding etiology of the viral hepatitis, it was HAV $260(83 \%), \mathrm{HEV}$ in $24(8 \%)$ and HBV in $15(4 \%)$. Dual infection with HAV and HEV was seen in six cases $(2 \%)$. In seven $(2 \%)$ patients the etiology was not confirmed (Figure 1).

\begin{tabular}{|llll|}
\hline \multicolumn{4}{|l|}{ Table 1. Demographic profile. } \\
\hline Age Group & \multicolumn{3}{l|}{ Acute Viral Hepatitis } \\
& Male & Female & Total \\
& 14 & 12 & 26 \\
0-5 years & 74 & 57 & 131 \\
6-10 years & 83 & 72 & 155 \\
11-15 years & 83 & 312 \\
Total & 171 & 141 & \\
\hline
\end{tabular}

\begin{tabular}{|c|c|c|c|}
\hline Symptoms & $\begin{array}{l}0-5 \text { years } \\
(n=26)\end{array}$ & $\begin{array}{c}6-10 \\
(n=131)\end{array}$ & $\begin{array}{c}11-15 \text { years } \\
(n=155)\end{array}$ \\
\hline Jaundice & $24(92 \%)$ & $124(95 \%)$ & $148(95 \%)$ \\
\hline $\begin{array}{l}\text { Loss of } \\
\text { appetite }\end{array}$ & $19(73 \%)$ & $126(96 \%)$ & $146(94 \%)$ \\
\hline Nausea & $15(58 \%)$ & $97(74 \%)$ & $126(81 \%)$ \\
\hline Vomiting & $24(92 \%)$ & $110(84 \%)$ & $116(75 \%)$ \\
\hline $\begin{array}{l}\text { Pain } \\
\text { abdomen }\end{array}$ & $10(38 \%)$ & $68(52 \%)$ & $105(68 \%)$ \\
\hline Itching & $8(30 \%)$ & $66(50 \%)$ & $84(54 \%)$ \\
\hline Dark urine & $24(92 \%)$ & $122(93 \%)$ & $148(95 \%)$ \\
\hline Fever & $24(92 \%)$ & $104(79 \%)$ & $101(65 \%)$ \\
\hline $\begin{array}{l}\text { Whitish } \\
\text { stool }\end{array}$ & $10(38 \%)$ & $41(31 \%)$ & 39 (25\%) \\
\hline
\end{tabular}




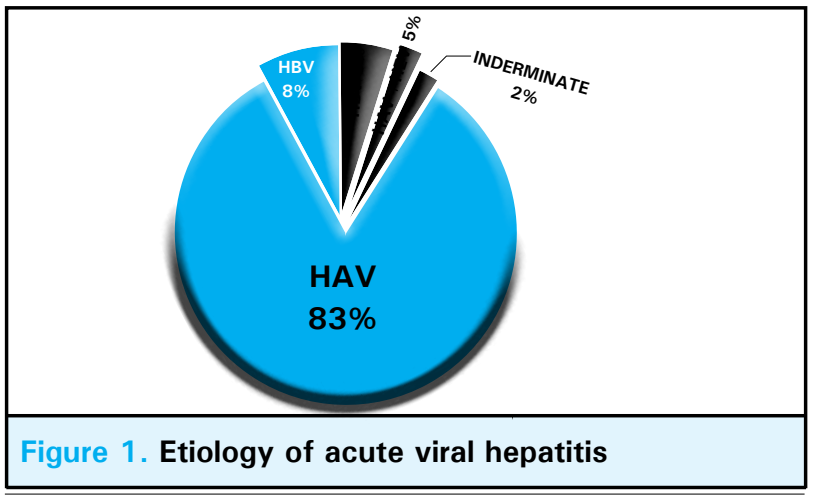

\section{Clinical outcome}

Most of the cases were managed from outpatient department. Only $27 \% \quad(85 / 312)$ patients were admitted. The indications for admissions were hyperacute liver failure $(n=5)$, coagulopathy $(n=14)$, acute pancreatitis $(n=2)$, secondary infections $(n=37)$, protracted vomiting (15)and bilirubin level more than $20 \mathrm{mg} / \mathrm{dL}(\mathrm{n}=12)$. The average duration for admission was 6.8 days (2-16 days). It was observed that 62 out of $85(73 \%)$ admitted patients were taking herbal medications before admissions. When compared among admitted patients, it was found that the hospital stay

\begin{tabular}{|llll|}
\hline Table 3. Laboratory parameters. \\
\hline Parameters & $\mathbf{0 - 5}$ years $(\mathbf{n}=\mathbf{2 6})$ & $\mathbf{6 - 1 0}(\mathbf{n}=\mathbf{1 3 1})$ & $\mathbf{1 1 - 1 5}$ years $(\mathbf{n}=\mathbf{1 5 5})$ \\
TLC & $4200-14200 \times 10^{3} \mathrm{~mm}$ & $3100-18900 \times 10^{3} \mathrm{~mm}$ & $5800-16000 \times 10^{3} \mathrm{~mm}$ \\
Total bilirubin & $2.1-16.4 \mathrm{mg} / \mathrm{dL}$ & $3.0-25.0 \mathrm{mg} / \mathrm{dL}$ & $1.2-32 \mathrm{mg} / \mathrm{dL}$ \\
Conjugated bilirubin & $1.0-12.3 \mathrm{mg} / \mathrm{dL}$ & $1.8-19.6 \mathrm{mg} / \mathrm{dL}$ & $0.8-27.7 \mathrm{mg} / \mathrm{dL}$ \\
ALT & $360-2100 \mathrm{IU} / \mathrm{mL}$ & $516-3900 \mathrm{IU} / \mathrm{mL}$ & $439-5170 \mathrm{IU} / \mathrm{mL}$ \\
AST & $296-1980 \mathrm{IU} / \mathrm{mL}$ & $350-2580 \mathrm{IU} / \mathrm{mL}$ & $632-4010 \mathrm{IU} / \mathrm{mL}$ \\
AP & $296-1280 \mathrm{IU} / \mathrm{mL}$ & $252-1160 \mathrm{IU} / \mathrm{mL}$ & $120-650 \mathrm{IU} / \mathrm{mL}$ \\
Albumin & $3.3-5.1 \mathrm{mg} / \mathrm{dL}$ & $3.0-5.0 \mathrm{mg} / \mathrm{dL}$ & $2.9-5.2 \mathrm{mg} / \mathrm{dL}$ \\
Prothrombin time & $11-16 \mathrm{sec}$ & $12-25 \mathrm{sec}$ & $12-27 \mathrm{sec}$ \\
\hline
\end{tabular}

The ultrasound findings are given in Table 4. Collapsed gall bladder with pericholecytic edema was most common finding. Ascites was present in $21 \%$ cases. However, it was mostly pelvic and patients were not subjected to any further testing. Walls of IHBD were prominent in about $25 \%$ cases, which are not commonly seen in adult cases of AVH. Those patients who were randomly selected to give ofloxacin did better than those who were not. Liver function test normalized earlier and ascites disappearance was earlier in antibiotics group (result not shown).

\begin{tabular}{|ll|}
\hline Table 4. Ultrasound findings. & \\
\hline USG Findings & $\mathbf{n ~ ( \% )}$ \\
Hepatomegaly & $244(78 \%)$ \\
Splenomegaly & $125(40 \%)$ \\
Collapsed (partial or complete) gall & $266(85 \%)$ \\
bladder & $284(91 \%)$ \\
Gall bladder wall thickening & $203(65 \%)$ \\
Pericholecysticedema & $150(48 \%)$ \\
Gall bladder sludge & $162(52 \%)$ \\
Prominent hilar node & $47(15 \%)$ \\
Ascites & $79(25 \%)$ \\
Prominent wall of IHBD & $32(10 \%)$ \\
Normal H-B scan &
\end{tabular}

was longer in patients who took herbal medications prior to admission. Ten patients were admitted due to altered sensorium. In 5 patients it was due to hyponatremia and corrected by $3 \% \mathrm{NaCl}$ solution. All 5 patients were on severe dietary restriction including no salt intake. Five patients suffered from hyperacute liver failure. All survived by conservative management in ICU set up. All patients were treated with SNMC (Stronger neo minophagen compound) at a dose of 20 $\mathrm{ml}$ twice a day along with other conventional medicines. L-ornithine L-aspartate was used in one case in which ammonia level was available and that was high. There were four re-admissions, all due to non-compliance of the medicines and two were due to worsening of the disease after consumption of herbal medications after discharge. There was no mortality in this study.

\section{DISCUSSION}

This study showed that HAV is the most common cause of $\mathrm{AVH}$ in pediatric population in Nepal. It is similar to a study from India where it was found that out of 172 studied, $111(64.5 \%)$ of children were found to have suffered from HAV. ${ }^{1}$ A study from Hong Kong showed that $81 \%$ of 348 studies suffered from hepatitis $A$ infection. ${ }^{2}$ Similar result was seen from Brazil. ${ }^{3}$ Although $\mathrm{HEV}$ is predominant causative agent in adult population, 
it was seen as etiological factor in $8 \%$ of pediatric AVH. This percentage is quiet low compared to two Indian studies. ${ }^{1,4}$ Hepatitis B virus was responsible in only 15 (4\%) patients. In 7 (2\%) patients the etiology was not confirmed. Late presentation or lack of antibody presentation by body's immune mechanism may be the reason for negative serology. We however, didn't look for serology for non-hepatotrophic viruses like Epstein Barr virus, Herpes simplex virus and cytomegalo virus. This is one of the pitfalls of the study. In this study multiple viral infection was very less. Only 6 cases $(2 \%)$ seen infected by HAV and HEV. This is far less that a study from India, where $24.6 \%$ cases of AVH in children were found to have multiple viral infections. ${ }^{5}$ There was no significant differences between single infection and dual infection in terms of clinical presentation or laboratory parameters.

Regarding symptoms, fever was one of the common presentations. However, this common symptom delayed the presentation. Patient who developed jaundice at the time of febrile illness attended outpatient department earlier. Other patients had attended Pediatric outpatient department and finally referred after blood test or development of jaundice. Most of the time fever was low grade, usually below 102 degree Fahrenheit. This finding is similar to a study from India. ${ }^{4,6}$ Incidence of liver failure was very low in our study. It was seen in only $1.6 \%$ of patient. All suffered from hyperacute liver failure with survival of $100 \%$. Mortality in a recent study from India was $1.3 \% .^{6}$

Ultrasound findings were little different when compared to findings in adult study conducted earlier. ${ }^{7}$ Ascites was more common in pediatric population. Yacha SK et al, in their study had described ascitic variety of AVH and Kamath et al reported ascites as atypical finding. ${ }^{8,9}$ In the study of Yacha et al, it was observed in $12.9 \%$ of patient studied, while it was in $15 \%$ in our study. The incidence of ascites in acute viral hepatitis not complicated by acute liver failure patient was $21.6 \%$ in another Indian study. ${ }^{1}$ The other difference we found was there was no clinically detectable ascites in our study population. It was presumed in their study that the low albumin was responsible for ascites formation. However, in our study the albumin level was not very low in patients presenting with ascites compared to others. Moreover, it was seen that those patients who had ascites also demonstrated prominent IHBD. Prominent IHBD was seen in about $25 \%$ cases, which was not observed in adult cases. Since the disappearance of ascites was earlier in those patient who were given antibiotics, one of the plausible etiology of ascites formation and prominent intrahepatic bile duct may be sub clinical infection.

Intake of herbal medications have been in vogue right from the Vedic period in Indian subcontinent at around $600 \mathrm{BC}$ and continues to be used even now for various forms of diseases, particularly presenting with jaundice. ${ }^{10,11}$ It is very usual to take herbs, either crude or purified, of different preparations.Taking herbal medicine in acute viral hepatitis is very common in our country and even in our sub-continent. The message from a review article in Hepatology is clear that herbal medicines in acute viral hepatitis are a ticket to more trouble. ${ }^{12}$ In our study it is clearly seen that morbidity was more when patient were taking herbal medications. Out of 85 admitted patients $73 \%$ were having herbal medicines at the time of admission. All four readmissions were due to herbal medicine intake.

\section{CONCLUSIONS}

Hepatitis $A$ is still common cause of acute viral hepatitis in pediatric population in Kathmandu. Improper use of herbal medications, secondary bacterial infection and faulty dietary intake was associated with prolonged illness. Patients with prominent biliary radicals, especially when associated with ascites should be treated with antibiotics even with normal blood counts for earlier recovery. Food fallacies should be well explained to the patient party for timely recuperation. Herbal medicine intake is still common in our part of the world. Patients had protracted course of illness as well as severe symptoms if there was history of intake of herbal medications.

\section{REFERENCES}

1. Thapa BR, Singh K, Singh V, Broor S, Singh V, Nain CK. Pattern of hepatitis A and hepatitis B virus markers in cases of acute sporadic hepatitis and in healthy school children from North West India. J Trop Paediatr. 1995;41:328-9.

2. Poddar U, Thapa BR, Prasad A, Singh K. Changing spectrum of sporadic acute viral hepatitis in Indian children. J Trop Pediatr. 2002Aug;48(4):210-3.
3. Chow CB, Lau TT, Leung NK, Chang WK. Acute viral hepatitis: aetiology and evolution. Arch Dis Child. 1989 Feb;64(2):211-3.

4. Pannuti CS, de Mendonça JS, Pereira ML, Carvalho MJ, Amato Neto V.Sporadic acute viral hepatitis A, B and non-A non-B. A prospective study of 150 consecutive cases in São Paulo, Brazil. Trop Geogr Med. 1985 Jun;37(2):136-8. 
5. Malathi S, Mohanavalli B, Menon T, Srilatha $\mathrm{P}$, Sankaranarayanan VS, Raju BB et al.Clinical and viral marker pattern of acute sporadic hepatitis in children in Madras, South India. J Trop Pediatr. 1998 Oct;44(5):275-8.

6. Kumar A, Yachha SK, Poddar U, Singh U, Aggarwal R. Does co-infection with multiple viruses adversely influence the course and outcome of sporadic acute viral hepatitis in children? J GastroenterolHepatol. 2006 Oct;21(10):1533-7.

7. Kumar KJ, Kumar HC, Manjunath VG, Anitha C, Mamatha S.Hepatitis A in children- clinical course, complications and laboratory profile. Indian J Pediatr. 2014 Jan;81(1):15-9.

8. KC S. Ultrasound findings in acute viral hepatitis. Kathmandu Univ Med J (KUMJ). 2006 Oct-Dec;4(4):415-8.
9. Yachha SK, Goel A, Khanna V, Poddar U, Srivastava A, Singh U. Ascitic form of sporadic acute viral hepatitis in children: a distinct entity for recognition. JPediatrGastroenterolNutr. 2010 Feb;50(2):184-7.

10. Kamath SR, Sathiyasekaran M, Raja TE, Sudha L.Profile of viral hepatitis A in Chennai. Indian Pediatr. 2009 Jul;46(7):642-3.

11. Navaneethan U, Venkatraman J. Herbal drugs in liver disease: how safe are they? Eur J GastroenterolHepatol. 2008 Mar;20(3):224-6.

12. Bernuau JR, Durand F. Herbal medicines in acute viral hepatitis: a ticketfor more trouble. EurJGastroenterolHepatol. 2008 Mar;20(3):161-3 